\title{
PENINGKATAN KEPERCAYAAN DIRI MELALUI KEGIATAN MENARI KREATIF PAUD BINTANG BESAR
}

\author{
I KETUT DINATA \\ PAUD Bintang Besar Bali \\ Email : dinata322@gmail.com
}

\begin{abstract}
ABSTRAK
Tujuan dari penelitian ini untuk mengambarkan proses penerapan kegiatan menari kreatif untuk meningkatkan kepercayaan diri di kelompok B Paud Bintang Besar . Penelitian tindakan kelas mengunakan model Kemmis dan Mc. Taggart. Subjek dari penelitian ini adalah di kelompok B Paud Bintang Besar yang berjumlah 10 anak. Langkah-langkah dalam penelitian ini yaitu: 1) Perencanaan; 2) Pelaksanaan; 3) Pengamatan; 4) Refleksi. Analisa data yang digunakan adalah kualitatif dan kuantitatif. Data kualitatifnya mengunakan model Miles and Hubberman. Penelitian ini dilakukan dalam dua siklus yaitu siklus I dan siklus II. Hasil akhir dari analisa data menunjukan peningkatan sebanyak pada siklus II $87,05 \%$ dari pra siklus sebanyak 26,25 $\%$ sampai pada siklus I 55,52\%
\end{abstract}

Kata Kunci: Menari Kreatif, Kepercayaan Diri dan Penelitian Tindakan.

\section{PENDAHULUAN}

Orang sukses memiliki kepercayaan diri yang baik dan merasakan bahwa mereka bisa berbuat sesuatu untuk dunia. Mereka memandang dunia ini adalah tempat dimana mereka ingin memainkan dan mengambil peran di-dalamnya. Mereka tetap berbuat sesuai kapasitas dan keterampilan yang mereka miliki, dan tetap menyadari bahwa keterampilan ini akan memberikan nilai kepada orang lain. Kepercayaan diri dapat membuat kita sukses sekaligus dapat membuat kita menjadi orang gagal jika kepercayaan diri berlebihan.

Kepercayaan diri adalah bagian dari konsep diri, konsep diri adalah dimensi harapan diri atau yang dicita-citakan dimasa depan. Ketika kita mempunyai sejumlah pandangan tentang siapa diri kita sebenarnya, pada saat yang sama kita juga mempunyai sejumlah pandangan lain tentang kemungkinan menjadi apa diri kita dimasa mendatang. Singkatnya kita juga mempunyai pengharapan bagi diri kita sendiri. Pengharapan ini merupakan diri-ideal (selfideal) atau diri yang dicita-citakan.

Anak usia dini menurut NAEYC adalah sosok individu yang sedang menjalani suatu proses perkembangan dengan pesat dan fundamental bagi kehidupan selanjutnya. Anak usia dini ada pada rentang usia 0-8 tahun. Menurut Berk dalam Desmita (2009: 146) pada masa ini proses pertumbuhan dan perkembangan dalam berbagai aspek sedang mengalami masa yang paling cepat dalam rentang perkembangan hidup manusia. Proses pembelajaran sebagai bentuk perlakuan yang diberikan kepada anak harus memperhatikan karakteristik yang dimiliki setiap tahapan perkembangan anak.

Widia Pekerti (2010: xi) mengungkapkan Apabila kita mengamati pelaksanaan seni di TK, kita sering menemui kenyataan bahwa praktek pembelajaran seni di sekolah-sekolah umum hanya sebatas kemampuan motorik saja. Sehingga esensi dari pendidikan seni pun belum tercapai. Padahal tujuan mengembangkan seni adalah bagaimana mengembangkan fisik, bahasa, sosial-emosional, moral serta kemampuan dasar bahasa, kognitik dan pra akademik. Maka dengan demikian terjadi ketimpangan dan permasalahan dalam pembelajaran seni di Taman Kanak-kanak (TK). Permasalahan di Taman Kanak-Kanak (TK) bukanlah permasalahan motorik saja, tapi semua aspek perkembangan harus dapat kita kembangkan secara optimal. Salah satunya yaitu perkembangan sosial emosionalnya misalnya kepercayaan diri. Kenyataan yang terjadi saat ini orang tua akan merasa bangga jika anaknya unggul dalam hal akademik dibandingkan potensi perkembangan dalam diri anak yang harus distimulasi. Seharusnya hal seperti itu tidak terjadi, Inilah awal pemangkasan potensi anak dimulai. Mahir 
dalam hal akademik namun tidak mahir dalam bersosialisasi atau bahkan minimnya kepercayaan diri.

Hal ini juga terjadi di Taman Kanak-Kanak (TK) satu atap Kramat Jati 25, dari dua puluh anak hanya ada sembilan atau sekitar $45 \%$ anak yang memiliki rasa kepercayaan diri, rendahnya kepercayaan diri anak-anak tersebut ditunjukan melalui anak cenderung diam dan tidak mau beranjak dari tempat duduk (keberanian) ketika disuruh guru melakukan suatu hal. Anak malumalu melakukannya (keberanian), anak terlihat malas-malasan (antusias), anak mengikuti instruksi guru dengan baik (ketekunan). Hal ini harus menjadi perhatian khusus untuk para guru-guru mengingat pentingnya meningkatkan kepercayaan diri.

Maka dengan melihat kenyataan ini penulis perlu melakukan peningkatan kepercayaan diri melalui kegiatan menari kreatif. Penulis memilih menari kreatif sebagai stimulasi karena dalam menari kreatif dapat mengungkapkan dan mengkomuniksikan, ide-ide, gagasan-gagasan, perasaan, pengalaman, kedalam bahasa tari. Estetika, menari kreatif tidak akan muncul jika tidak memiliki rasa kepercayaan diri. Maka rasa kepercayaan diri akan menjadi kebiasaan bagi anak. Dari kebiasaan tersebut akan membentuk sikap kepercayaan diri anak. Melalui kegiatan menari kreatif diduga dapat meningkatkan kepercayaan diri anak. Untuk itulah Penulis melakukan penelitian meningkatkan kepercayaan diri melalui kegiatan menari kreatif, agar sejak dini kepercayaan diri anak dapat dikembangkan seoptimal mungkin.

\section{A. Kepercayaan Diri}

Hakim dalam Rahayu (2013: 63) menyatakan bahwa kepercayaan diri adalah keyakinan seseorang membuat kemampuan untuk mencapai berbagai tujuan hidup. Pemily dalam Desmita (2009:164) mengatakan bahwa konsep diri sebagai sistem yang dinamis dan kompleks dari keyakinan yang dimiliki seseorang tentang dirinya, termasuk sikap, perasaan, persepsi, nilainilai dan tingkah laku yang unik dari individu tersebut. Feldman dalam Yamin dan Sanan (2013: 13) mengatakan konsep diri merupakan penerimaan diri seseorang akan dirinya sendiri atau tingkatan penilaian orang tentang harga diri seorang yang menghargai dirinya apa adanya.

Lie dalam Rahayu (2013: 69) juga mengemukakan tentang ciri-ciri perilaku yang mencerminkan kepercayaan diri tinggi, yakni kepada diri sendiri, tidak tergantung pada orang lain, tidak ragu-ragu merasa diri berharga, tidak menyombongkan diri, dan memiliki rasa keberanian untuk bertindak. Serupa dari pendapat, Lautser memaparkan secara terperinci bahwa ciri-ciri dari kepercayaan diri yaitu tidak mementingkan diri sendiri, cukup toleran, tidak membutuhkan dukungan orang lain secara berlebihan, bersikap optimis, dan gembira. Sejalan dengan pendapat sebelumnya, Maslow mengemukakan bahwa kepercayaan diri memiliki kemerdekaan psikologis, yang berarti kebebasan mengarahkan pikiran dan mencurahkan tenaga berdasarkan pada kemampuan dirinya, untuk melakukan hal-hal yang bersifat produktif, menyukai pengalaman baru, suka menghadapi tantangan, pekerjaan yang efektif, dan bertanggung jawab dengan tugas yang diberikan.

Lain halnya dengan Bandura dalam Santrock (2009: 216) efikasi diri (self-efficacy) keyakinan bahwa seseorang dapat menguasai sesuatu dan memberikan hal positif. Menurutnya efikasi diri dapat menentukan siswa akan berprestasi atau tidak. Tiga jenis kepercayaan diri yang perlu dikembangkan pada anak, antara lain: (1) Tingkah laku, merupakan kepercayaan diri untuk mampu bertindak dan menyelesaikan tugas-tugas yang paling sederhana. Misalnya ketika guru memberikan tugas menari kreatif di depan kelas, anak mampu melakukannya; (2) Emosi, merupakan kepercayaan diri untuk yakin dan mampu menguasai seluruh sisi emosi. Maksudnya, ketika anak diberi tugas untuk menari kreatif, emosi anak terlihat sangat antusias dan penuh kegembiraan; dan (3) Spiritual (agama), merupakan keyakinan bahwa hidup ini memiliki tujuan positif.Dalam hal ini anak diajarkan konsep keagamaan yang dianutnya dalam kegiatan sehari-hari. Misalnya, kegiatan menari kreatif meniru gerakan binatang,tumbuhtumbuhan,air yang mengalir ombak yang bergelombang itu menunjukkan kebesaran Sang Pencipta. 
Dari definisi para ahli tersebut dapat disintesiskan bahwa kepercayaan diri merupakan keyakinan yang bersifat kompleks dan dinamis yang dimiliki seseorang untuk mencapai tujuan yang harapkan. Keyakinan tersebut dapat berupa berupa tingkah laku, emosi dan spiritual. Keyakinan yang ada ini senantiasa tercermin dalam kehidupan sehari-hari. Anak yang memiliki rasa kepercayaan diri memiliki ciri-ciri yaitu tidak mementingkan diri sendiri, cukup toleran, tidak membutuhkan dukungan orang lain secara berlebihan, bersikap optimis, gembira, yang bersifat produktif, menyukai pengalaman baru, suka menghadapi tantangan, pekerjaan yang efektif dan bertanggung jawab dengan tugas yang diberikan.

\section{B. Menari Kreatif}

Kasudiardjo (1992: 11) mengatakan kesenian adalah bagian dan kebudayaan. Seni tari adalah salah satu bagian dan kesenian arti tari adalah keindahan gerak anggota-anggota badan manusia yang bergerak, berirama dan berjiwa atau dapat diberi arti bahwa seni tari adalah keindahan bentuk anggota badan manusia yang bergerak, berirama dan berjiwa yang harmonis.

Menurut Hawkins (1990:2) tari adalah ekspresi jiwa manusia yang diubah oleh imajinasi dan diberi bentuk melalui media gerak sehingga bentuk gerak yang simbolis dan sebagai ungkapan pencipta. Dalam bahasa lain dapat kita ungkapkan bahwa tari merupakan ungkapan ekspresi jiwa yang digambarkan dalam bentuk gerak. Menurut Tim Estetika (2000: 10) merupakan salah satu cabang seni yang mengunakan gerak tubuh sebagai alat ekspresi. Jadi gerak tubuh merupakan media untuk mengekspresikan diri.

Senada dengan Soedarsono (2000:4-5) yang mengatakan bahwa tari adalah desakan perasaaan manusia tentang "sesuatu" yang disalurkan melalui gerak-gerak ritmis yang indah. Artinya Tari merupakan bentuk komunikasi perasaan manusia yang diekspresikan melalui gerakan sehingga orang yang menonton akan mengerti. Namun dalam gerakan-gerakan badan mengandung ritmis yang indah yang berfungsi untuk menari kreatif perhatian penonton.

Menurut Suryodiningrat (1980: 90) tari juga didefinisikan sebagai gerakan dari seluruh bagian tubuh manusia yang disusun selaras dengan irama musik dan memiliki maksud tertentu. Menari kreatif adalah menyamakan antara gerak dan irama musik. Hal ini senada dengan Soeryobrongoto (1987: 87) yang mengatakan bahwa tari merupakan gerak anggota tubuh yang selaras dengan bunyi musik. Menari kreatif adalah setiap gerakan-gerakan harus selaras antara irama dan gerak.

Dari berbagai pendapat para ahli tersebut dapat disintesiskan bahwa tari kreatif adalah keindahan bentuk anggota badan manusia yang bergerak, berirama dan berjiwa yang harmonis yang merupakan ekspresi jiwa yang diwujudkan dalam gerak yang selaras dengan musik sehingga menarik perhatian penonton.

\section{METODE PENELITIAN}

Metode dalam penelitian ini adalah metode penelitian tindakan yang menggunakan model Kemmis dan Taggart. Yang terdiri dari empat komponen, yaitu: perencanaan (planning), tindakan (acting), pengamatan (observing), dan refleksi (reflecting). Tekhnik pengumpulan data dalam penelitian ini adalah menggunakan (a) Observasi Pemantau Tindakan pada anak dan guru (b) Wawancara dan (c) Dokumentasi. Jenis instrumen yang digunakan adalah menggunakan non tes berupa lembar observasi, yang terdiri dari, lembar observasi pemantauan tindakan.

Teknik analisis data yang dilakukan dalam penelitian ini adalah melalui dua cara yaitu teknik analisis kuantitatif deskriptif dan data kualitatif. Statistika deskriptif untuk membandingkan hasil yang diperoleh dari siklus pertama dan siklus kedua berupa rata-rata angka hitung (mean) dan perhitungan/pengukuran berbentuk prosentase. Analisis data kualitatif dilakukan terhadap data yang dikumpulkan melalui wawancara, catatan lapangan peneliti, dan refleksi. Analisis data kualitatif mengunakan teknik menurut Miles dan Huberman (1992: 1620) yang terdiri dari: data reduction, data display, data conclusing drawing/verification. 


\section{HASIL DAN PEMBAHASAN}

Hasil penelitian dan pembahasan menunjukkan bahwa kepercayaan diri meningkat dari tiap siklusnya.

\section{A. Pra-Siklus}

Dari data kepercayaan diri pada anak pra-penelitian dapat disajikan dalam bentuk grafik maka hasilnya sebagai berikut:

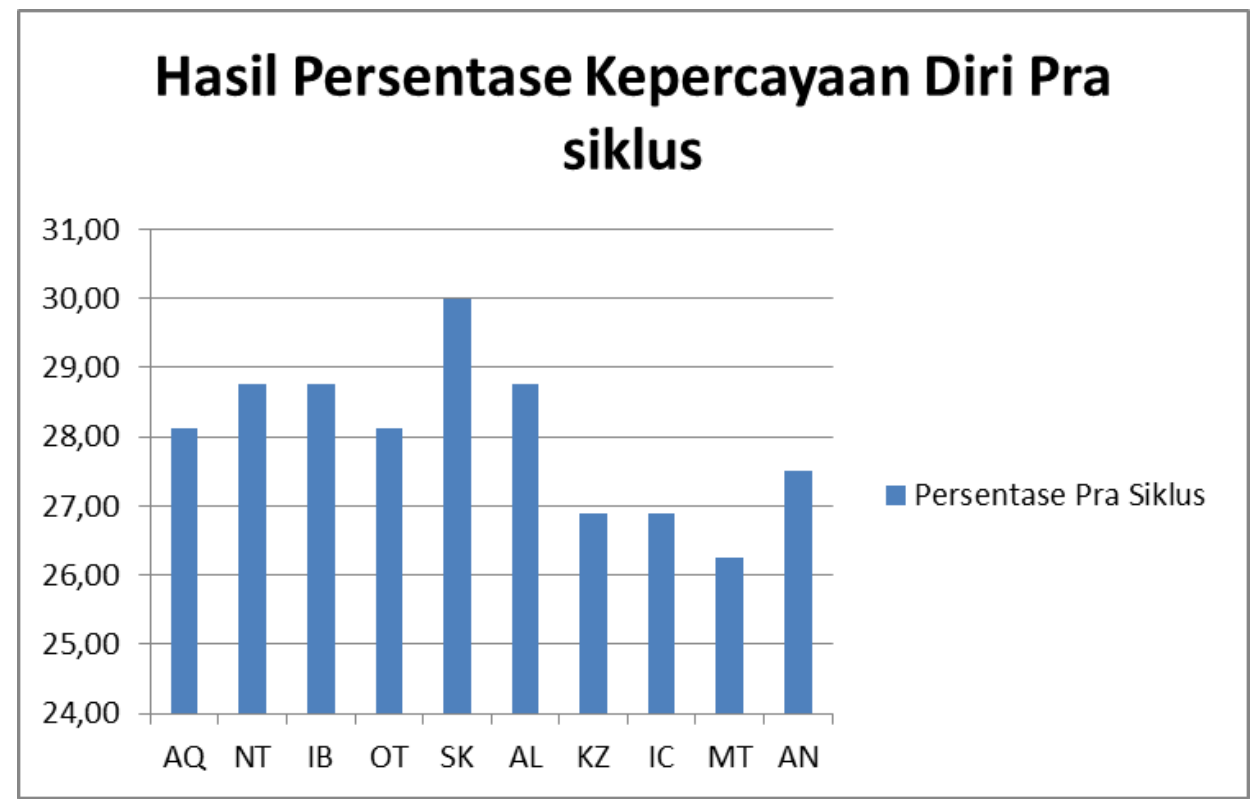

Gambar 1. Grafik Kepercayaan Diri Pra Siklus

Grafik tersebut mengambarkan bahwa kepercayaan diri di Paud Bintang Besar yaitu persentase $32,57 \%$.

Setelah mengetahui hasil peneliti bersama kolaborator melakukan analisis dan berdiskusi tentang hasil dari assesmen pra siklus. Setelah dianalisa secara mendalam. Maka peneliti dan kolaborator memutuskan untuk melaksanakan tindakan intervensi yaitu pelaksanaan siklus I karena nilai hasil assesmen pra siklus berada dibawah das sein dan masih jauh dari standar keberhasilan yang telah disepakati antara kolaborator dan peneliti yakni $71 \%$.

\section{B. Siklus I}

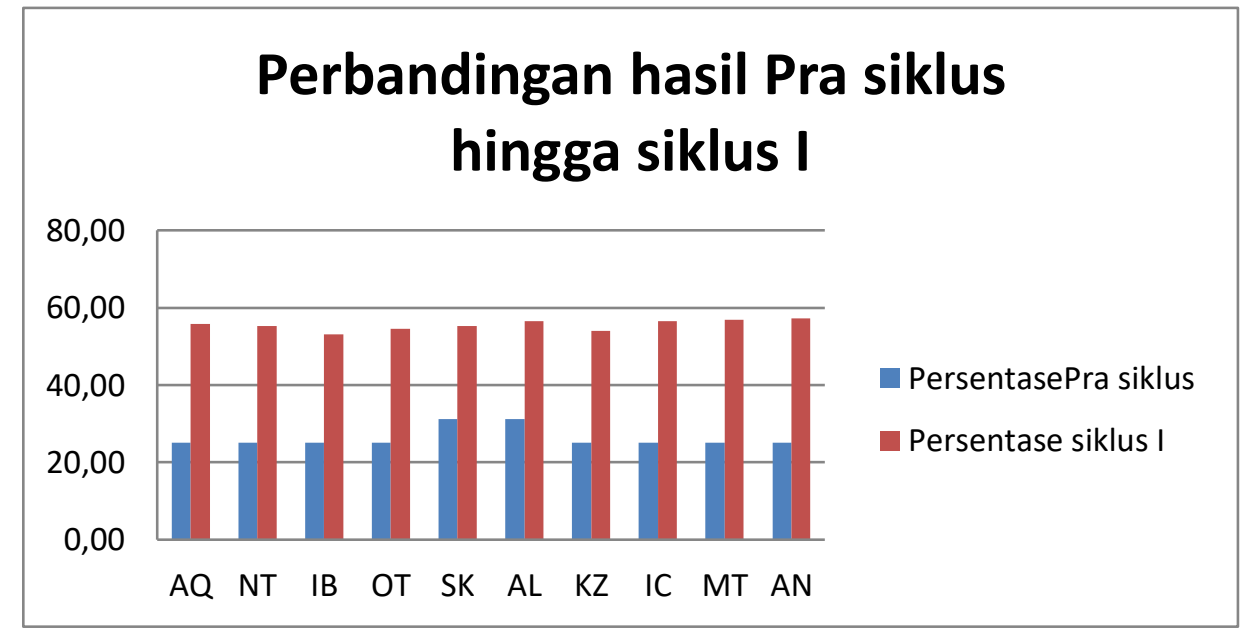

Gambar 2. Grafik Perbandingan Pra Siklus Hingga Siklus I

Berdasarkan hasil tabel dan grafik di atas, diperoleh data tentang peningkatan kepercayaan melalui tari kreatif pada Pelaksanaan anak pada siklus I. Secara klasikal sebesar 
persentase 55,52 \% artinya pelaksanaan pada siklus I belum mencapai kriteria keberhasilan yang telah disepakati diawal bersama kolaborator dan mastery learning yang ada di sekolah yakni sebesar $71 \%$.

Maka peneliti melanjutkan ke siklus II namun sebelum melanjutkan Peneliti dan kolaborator melakukan refleksi setelah pelaksanaan siklus I telah selesai dilaksanakan. Ada beberapa hal yang menjadi bahan refleksi peneliti dan kolaborator pada siklus I baik itu berupa kelemahan maupun kelebihan. Adapun hasil refleksi tersebut, yaitu:

1. Anak duduk belum membentuk huruf $U$ karena mereka penasaran dengan gambar lebah dan film lebah yang diputar oleh guru

2. Ketika guru menjelaskan ada anak yang tidak peduli dengan penjelasan guru.

3. Guru tidak menyampaikan tema pembelajaran pada saat akan mulai mengajar.

4. Guru belum memberikan kesimpulan

5. Anak-anak bermain-main dilayar saat penayangan film sehingga menganggu penjelasan guru.

\section{Siklus II}

Adapun hasil dari siklus II adalah sebagai berikut:

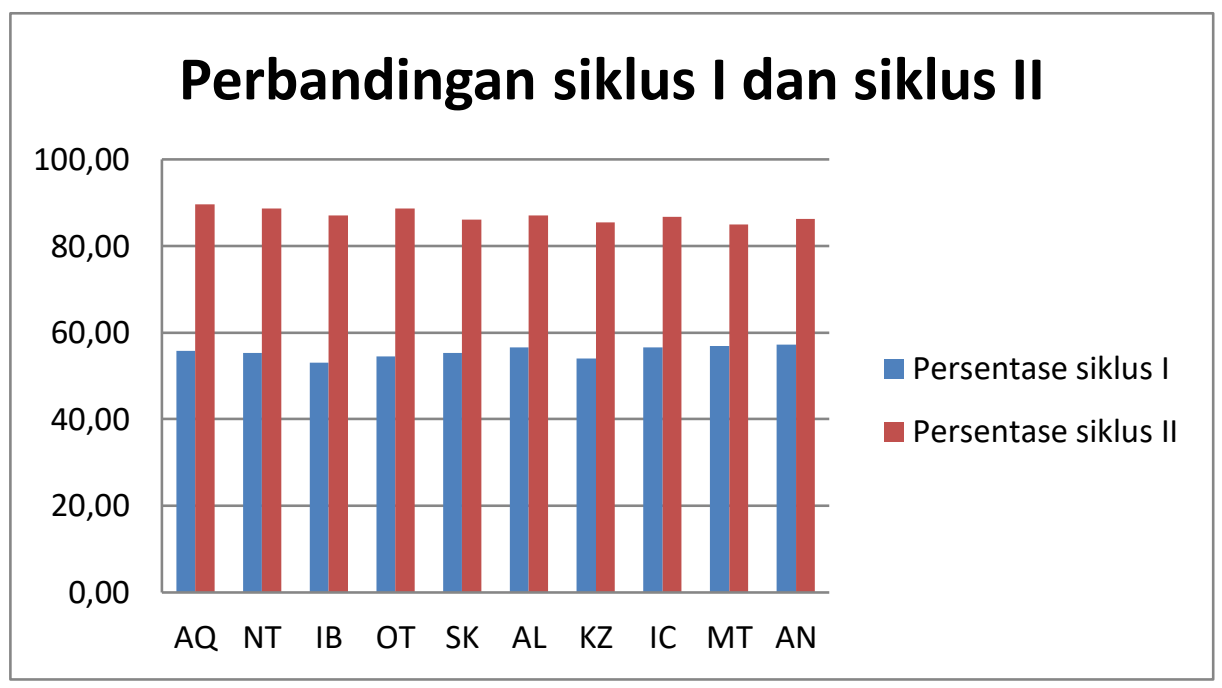

Gambat 3. Grafik Hasil Asesmen Kepercayaan Diri Siklus II

Berdasarkan hasil tabel dan grafik di atas, diperoleh data tentang peningkatan kepercayaan melalui tari kreatif pada pra-siklus yang mencapai persentase $26,25 \%$ pada siklus I sebesar persentase 55,52 \% sedangkan pada siklus II sebesar 87,05\% artinya pelaksanaan peningkatan kepercayaan diri mencapai kriteria keberhasilan yang telah disepakati diawal bersama kolaborator dan mastery learning yang ada di sekolah yakni sebesar $71 \%$.

Berikut hasil asesmen kepercayaan diri dari pra siklus, siklus I hingga siklus II: 


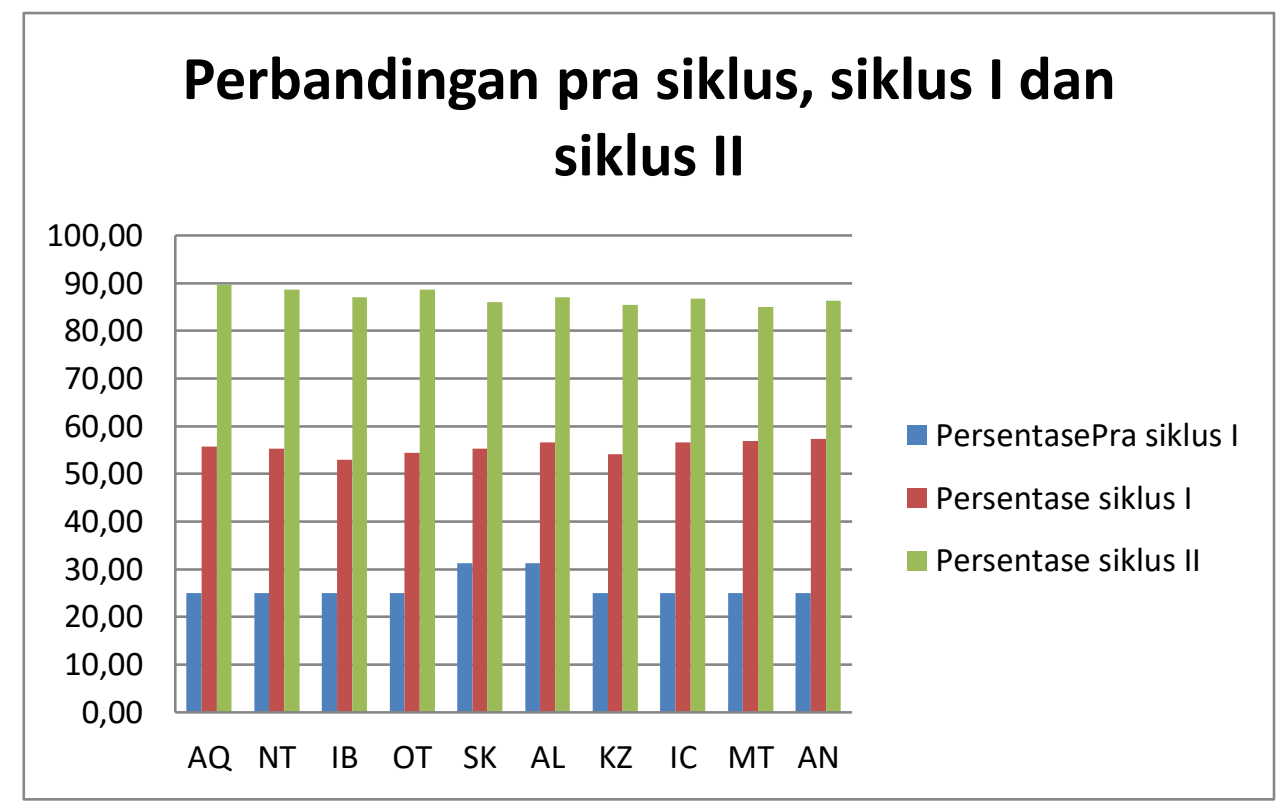

Gambar 4. Grafik Perbandingan Kepercayaan Diri dari Pra Siklus, Siklus I dan Siklus II

Berdasarkan data di atas terlihat bahwa skor rata-rata persentase sebesar 26,25\% pada pra siklus. kemudian mengalami peningkatan pada siklus I 29,27 \% sehingga menjadi 55,52 \%, selanjutnya dari siklus I ke Siklus II Kepercayaan diripada anakmengalami peningkatan sebesar $31,53 \%$ menjadi sebesar $87,05 \%$. Sehingga total peningkatan kepercayaan diri melalui tari kreatifdari pra siklus, siklus I sampai siklus II sebesar 60,08 \%.

Berdasarkan perolehan data secara kuantitatif dan kualitatif, hasil Penelitian ini telah membuktikan bahwa tari kreatif dapat meningkatkan kepercayaan diri pada anak TK B Paud Bintang Besar.

Pada akhir pra siklus, siklus I dan II Peneliti dan kolaborator melakukan perhitungan terhadap hasil observasi peningkatan kepercayaan diri. Berdasarkan data hasil tindakan yang telah dilakukan terhadap 10 responden, pada saat pra siklus diketahui bahwa kepercayaan diri anak diperoleh rata-rata persentase $26,25 \%$ pada siklus I diperoleh 55,52 \% jadi dari pra siklus hingga siklus I meningkat sebesar 29,27 \%. Pada siklus II diperoleh persentase sebesar 87,05 $\%$ maka dari siklus I ke siklus II meningkat sebesar 31,53\%, sehingga apabila dihitung terjadi peningkatan sebesar $60,80 \%$ dari pra siklus hingga siklus II.

Bila ditinjau dari berbagai kajian ilmu maka kepercayaan diri melalui tari kreatif ada hubungannya dengan berbagai disiplin ilmu. Dalam bidang pendidikan misalnya teori pieget menjelaskan bahwa anak yang berusia 2-7 tahun anak mulai mempersentasikan dunia dengan kata-kata dan gambar-gambar. Kata dan gambar menunjukan adanya peningkatan pemikiran simbolis dan melampui batas hubungan informasi sensor dan tindakan fisik. Ketika anak-anak kepercayaan diri dia akan berani mengemukakan ide dan gagasan yang dimilikinya di depan orang banyak.

Dalam teori pembelajaran yang dikemukakan John Dewey mengatakan bahwa learning by doing (belajar dengan melakukan). Mengajarkan karakter anak tidak hanya cukup dengan kata-kata tapi dapat dilakukan dengan gerakan atau dengan menari karena dengan kegiatan menari mereka akan tampil dihadapan orang banyak.

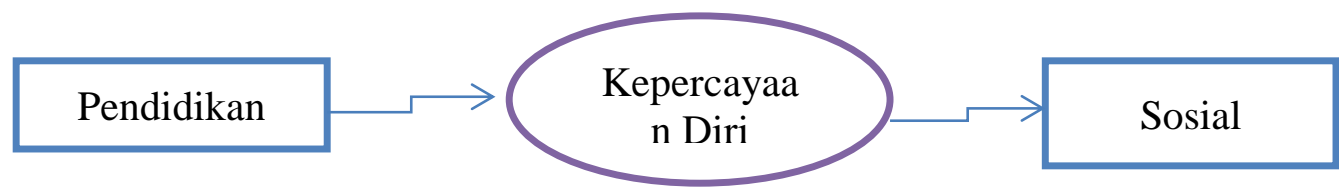

Gambar 5. Bagan Multidipliner Kepercayaan diri melalui tari kreatif 
Dalam ilmu sosial misalnya sebagaimana Edwi (2011: 83) mendefinisikan sosiologi adalah ilmu yang mempelajari hubungan sosial antara sesama manusia (individu dan individu), antara individu dan ide-ide social. Penelitian ini akan bermanfaat untuk kesuksesan anak dalam bersosialisasi dengan lingkungan karena dengan anak kepercayaan diri yang baik maka akan memudahkan mereka berinteraksi dengan siapapun.

\section{KESIMPULAN}

berikut:

Berdasarkan hasil analisis data dalam pembahasan, maka dapat disimpulkan sebaai

1. Proses peningkatan kepercayaan diri pada anak TK B Paud Bintang Besar melalui tari kreatif. Adapun pengembangan dalam proses pembelajaran peningkatan kepercayaan diri mengunakan media-media gambar dan film lebah pada siklus I, pada siklus II anak melatih kepercayaan dirinya dengan menarikan tari kreatif bertema lebah. Adapun langkahlangkah dalam pelaksanaan peningkatan Kepercayaan diri dimulai dimulai dengan menonton gambar lebah maupun film lebah guna memancing ide dan gagasan anak sehingga mereka berani untuk menerima tantangan menciptakan gerakan-gerakan tari kreatif yang bersumber pada binatang lebah, setelah itu mereka diberikan tantangan untuk menarikan tari kreatif bertema lebah.

2. Hasil dari tari kreatif dapat meningkatkan kepercayaan diri. Hal ini dibuktikan Pada akhir pra siklus, siklus I dan II Peneliti dan kolaborator melakukan perhitungan terhadap hasil observasi peningkatan kepercayaan diri. Berdasarkan data hasil tindakan yang telah dilakukan terhadap 10 responden, pada saat pra siklus diketahui bahwa kepercayaan diri anak diperoleh rata-rata persentase 26, $25 \%$ pada siklus I diperoleh 55,52 \% jadi dari pra siklus hingga siklus I meningkat sebesar 29,27 \%. Pada siklus II diperoleh persentase sebesar 87,05 \% maka dari siklus I ke siklus II meningkat sebesar 31,53\%, sehingga apabila dihitung terjadi peningkatan sebesar $60,80 \%$ dari pra siklus hingga siklus II.

\section{DAFTAR PUSTAKA}

Desmita. (2009). Psikologi Perkembangan. Bandung: Rosdakarya.

Hawkins, Alma. (1990). Mencipta Lewat Tari terj. Yogyakarta: ISI Sumandiyo Hadi.

M. Jazuli, Soeyobrongoto. (1987). Kebudayaan. Bandung: STSI Press.

Rahayu, Aprianti Yovita. (2013). Menumbuhkan Kepercayaan Diri Melalui Bercerita. Jakarta: Indeks.

Tilaar, HAR. (2015). Pedagogik Teoritis untuk Indonesia. Jakarta: Kompas Gramedia.

Sanan, Sabri dan Martinis Yamin dan Jamilah. (2013). Panduan PAUD: Pendidikan Anak Usia Dini. Jakarta: Gaung Presada Press Group.

Kassudiardjo, Bagong. (2005). Bagong Kussudiardja Dari Klasik Hingga Kontemporer . Yogyakarta: Padepokan Press.

Soedarsono, et al. (2010). Indonesia Indah: Tari Tradisional Indonesia. Jakarta: Harapan Kita TMII/BP.

Soeryadiningrat. (1980). Babad lan Mekaring Djoget Djawi. Yogyakarta: Kombuning. 